\title{
Tryptophan availability and serotonin synthesis
}

\author{
By Peter D. Leathwood, Nestlé Research Department, NESTEC Ltd, 55 \\ avenue Nestlé, CH-1800 Vevey, Switzerland
}

Under carefully chosen experimental conditions, the consumption of specific diets or the administration of appropriate precursor amino acids can influence the synthesis of serotonin and catecholamines in the brain (Fernstrom, 1983; Sved, 1983). Thus, if rats are starved overnight and then given a carbohydrate-rich, protein-free meal, brain serotonin (5-hydroxytryptamine, $5 \mathrm{HT}$ ) increases; if the meal is rich in protein, brain ${ }_{5} \mathrm{HT}$ may fall (Fernstrom \& Wurtman, 1971, 1972; Leathwood, I 986 ). The mechanism by which diet (or tryptophan; TRP) is thought to influence ${ }_{5} \mathrm{HT}$ synthesis involves the following sequence: the composition of food consumed changes plasma levels of the large neutral amino acids (LNAA), which affect in turn the rate of TRP transport into the brain, brain TRP levels and hence the rate of ${ }_{5} \mathrm{HT}$ synthesis. It has been suggested that, by this mechanism, dietary interventions might influence a range of behaviours and brain functions linked to serotoninergic neurotransmission. The objective of the present review is to examine each step in the long sequence of (proposed) causality in an attempt to define the circumstances under which each step may have functional significance.

\section{$T R P$ availability and brain serotonin synthesis}

Serotonin in the brain is synthesized from the essential amino acid TRP. The rate-limiting step is the hydroxylation of TRP to 5-hydroxytryptophan by the enzyme tryptophan 5 -monooxygenase ( $E C$ I.I 4.16.4). The rate of this reaction is influenced by a variety of factors including TRP concentration, the firing frequency of the neuron, $\mathrm{Ca}^{2+}$-dependent phosphorylation of the enzyme and cofactor availability (Fernstrom, 1983). End-product inhibition has been reported when brain ${ }_{5} \mathrm{HT}$ levels are tripled or quadrupled by monoamine oxidase $(E C$ I.4.3.4) inhibitors (Macon et al. 1971), but his mechanism does not seem to act at physiological levels of ${ }_{5} \mathrm{HT}$ (Fernstrom, 1983 ).

The Michaelis-Menten constant $\left(K_{m}\right)$ of the enzyme for TRP is about $50 \mu \mathrm{M}$, both in vitro (Kaufman, 1974) and in vivo (Sved, 1983), although recent studies with isolated synaptosomes suggest that the apparent $K_{m}$ might be much lower (Wolf \& Kuhn, 1986). Brain levels of TRP usually range between Io and $30 \mu \mathrm{M}$, so that the enzyme is probably unsaturated and changes in brain TRP should change the rate of ${ }_{5} \mathrm{HT}$ synthesis. Numerous experiments have demonstrated that this is so. Increasing brain TRP not only increases the rate of ${ }_{5} \mathrm{HT}$ synthesis (Carlsson \& Lindqvist, 1972), it increases concentrations of brain ${ }_{5} \mathrm{HT}$ and 5 -hydroxyindoleacetic acid (5HIAA) (Hess \& Doepfer, 196r; Fernstrom et al. 1974). In man, it increases cerebrospinal fluid (CSF) levels of ${ }_{5}$ HIAA (Eccleston et al. 1970; 
Gillman et al. $198 \mathrm{I})$. Lowering brain TRP decreases the rate of ${ }_{5} \mathrm{HT}$ synthesis and lowers brain ${ }_{5} \mathrm{HT}$ and ${ }_{5} \mathrm{HIAA}$ concentrations (Biggio et al. 1974; Arimanana et al. 1984 .

In general, it appears that a doubling of brain TRP (from about 15 to $30 \mu \mathrm{M}$ ) produces a $20-30 \%$ rise in brain ${ }_{5} \mathrm{HT}$ and ${ }_{5} \mathrm{HIAA}$ (Fernstrom \& Wurtman, 1972; Fernstrom et al. 1974; Arimanana et al. 1984). The dose-response curve flattens off as brain TRP approaches $90 \mu \mathrm{M}$ (the concentration at which TRP 5-monooxygenase should be saturated). The results of Young \& Gauthier (1981) suggest that a similar saturation may also occur in man since a $3 \mathrm{~g}$ load of TRP approximately doubles $\mathrm{CSF}{ }_{5} \mathrm{HIAA}$ while a $6 \mathrm{~g}$ load produces no further increase.

\section{Transport of TRP into the brain}

TRP is carried across the blood-brain barrier by the LNAA transport system, so it must compete with valine, leucine, isoleucine, tyrosine, phenylalanine and methionine for access to the carrier-binding site (Pardridge, 1983 ). The $K_{m}$ of the carrier for TRP in the absence of competing LNAA is approximately $0.1 \mathrm{mM}$. The apparent $K_{m}$ (i.e. taking into account the concentrations and binding constants of the competing LNAA) varies between 0.4 and $0.6 \mathrm{~mm}$. Since total plasma TRP usually ranges between 0.04 and $0.1 \mathrm{mM}$, the binding site is unsaturated with respect to TRP, and if plasma TRP levels change while other LNAA remain constant, the rate of TRP transport into the brain will also change. Since the other LNAA compete with TRP for transport, a change in their concentrations will equally influence TRP entry into the brain, even if plasma TRP remains constant. This is illustrated in Fig. I where similar amounts of TRP given alone or in combination with an amino acid mix produce very different effects on brain TRP and ${ }_{5} \mathrm{HT}$. Under these circumstances the plasma TRP:LNAA ratio is a good predictor of brain TRP and ${ }_{5} \mathrm{HT}+{ }_{5} \mathrm{HIAA}$ (the normal range of this ratio is shown in Fig. I). As can be seen, a fourfold rise in the ratio doubles brain TRP which in turn produces a $20 \%$ rise in ${ }_{5} \mathrm{HT}+{ }_{5} \mathrm{HIAA}$.

The picture is further complicated by the reversible binding of TRP to albumin. Estimates of dialysable tryptophan suggest that only $15-20 \%$ of plasma TRP is 'free' but, as Pardridge ( 1983 ) has pointed out, interactions which are valid at equilibrium in vitro do not necessarily hold in vivo. During passage through the capillary bed of the brain the TRP-albumin complex disassociates and reassociates many times, while the LNAA carrier is competing for TRP. Pardridge ( 1983 ) estimates that $70-80 \%$ of total plasma TRP will be available for transport so that albumin binding should play only a minor role in determining the rate of TRP transport into the brain. Even so, measurements both in rats (Leathwood, I986) and men (Pérez-Cruet et al. 1974) suggest that taking into account both albumin binding and competition with LNAA may slightly improve the predictability of brain TRP or CSF serotonin metabolites.

Until recently, there was some disagreement between different research groups as to which of plasma free TRP, plasma TRP:LNAA or plasma free TRP:LNAA best predicts brain TRP and ${ }_{5} \mathrm{HT}$. An experiment which helps resolve this 

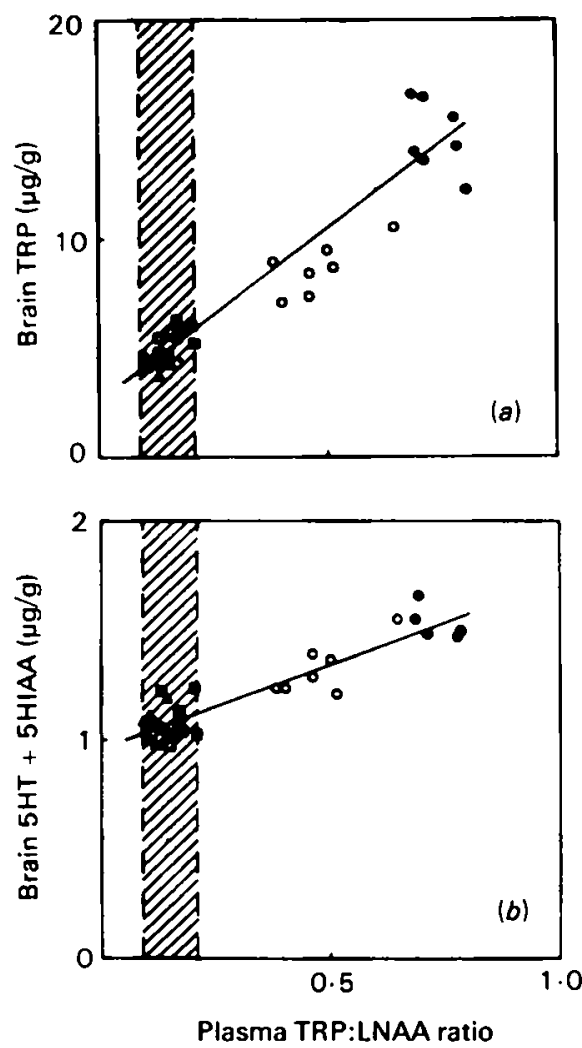

Fig. I. Correlation between $(a)$ brain tryptophan (TRP) and $(b)$ brain serotonin ( 5 -hydroxytryptamine, ${ }_{5} \mathrm{HT}$ ) plus 5 -hydroxyindoleacetic acid $(5 \mathrm{HIAA})$ and the ratio of TRP:large neutral amino acids (LNAA), (LNAA comprise TRP, leucine, isoleucine, valine, phenylalanine, tyrosine and methionine).

Rats were starved for $18 \mathrm{~h}$ and fed nothing, a complete amino acid mix or an amino acid mix minus the LNAA which compete with TRP. Treatments were as follows: starved controls I $h(\Delta)$,

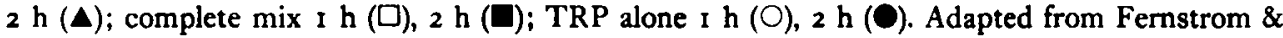
Wurtman (1972). ( Range of plasma TRP:LNAA ratios seen in free-feeding rats (Leathwood \& Ashley, $1983 a, b)$.

question is illustrated in Figs. 2 and 3 where, in rats starved overnight and then given meals of different compositions, the TRP:LNAA and free TRP:LNAA ratios are the better predictors of brain TRP. In this particular example plasma TRP and free TRP correlate negatively with brain TRP. Fig. 3 illustrates another important point. Although the correlation between plasma TRP:LNAA and brain TRP is rather tight, the correlation with ${ }_{5} \mathrm{HT}+{ }_{5} \mathrm{HIAA}$ is less reliable. The same conclusion can be drawn from an examination of Fig. I. Over the full range, TRP:LNAA did predict ${ }_{5} \mathrm{HT}+{ }_{5} \mathrm{HIAA}$, but within the normal range the correlation is weak. This point will be taken up again during discussion of theories of serotoninergic control of protein-carbohydrate selection. 

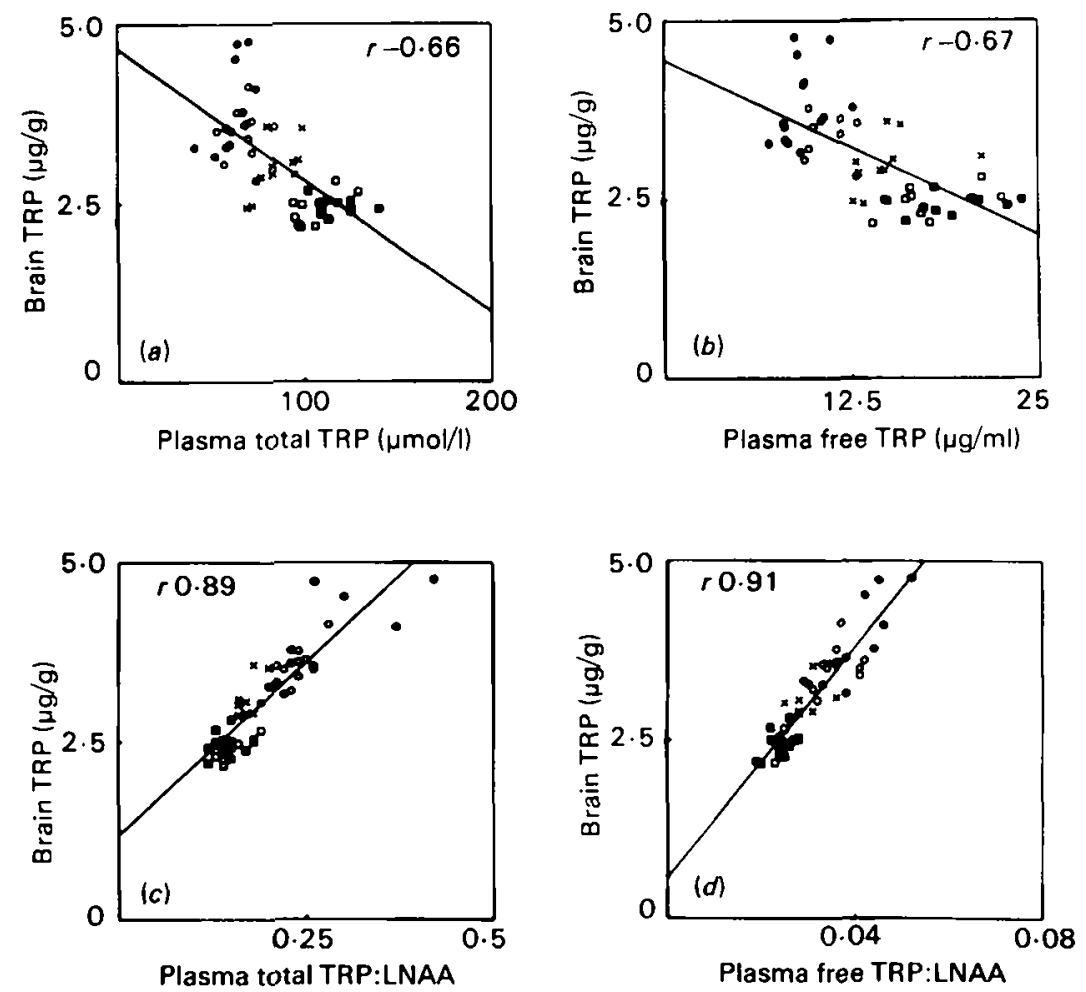

Fig. 2. Correlations between brain tryptophan (TRP) and (a) plasma total TRP, (b) plasma free TRP, (c) plasma total TRP:large neutral amino acids (LNAA) ratio, (d) plasma free TRP:LNAA ratio in rats fed on different meals following a $15 \mathrm{~h}$ overnight fast. Compositions of the meals were as follows: $2.5 \mathrm{~g}(O)$ or $5.0 \mathrm{~g}(\Theta)$ of a high-carbohydrate, protein-free diet; $2.5 \mathrm{~g}(\square)$ or $5.0 \mathrm{~g}(\square)$ of a $200 \mathrm{~g}$ protein/kg diet; fasted control $(\mathbf{x})$.

\section{Effects of diet or TRP, or both on plasma TRP:LNAA ratio}

Figs. 2 and 3 also illustrate the effects of carbohydrate- or protein-containing meals (eaten after an overnight fast) on plasma TRP:LNAA ratio and brain ${ }_{5} \mathrm{HT}$. The carbohydrate meal produces a sharp rise in insulin which accelerates uptake of glucose and branched-chain amino acids into muscle. Thus, although TRP levels fall slightly, the TRP:LNAA ratio rises, and brain TRP and ${ }_{5} \mathrm{HT}$ increase. After the meal containing protein, plasma levels of all the LNAA rise. In this particular example the protein meal actually lowered the TRP:LNAA ratio (and brain TRP and ${ }_{5} \mathrm{HT}$ ) in spite of a rise in plasma TRP. The size of the meals had no significant influence on the ratio or on ${ }_{5} \mathrm{HT}$ metabolism.

Does the same phenomenon occur in 'free-feeding' rats (or people)? In rats, after a short $(3 \mathrm{~h})$ fast a carbohydrate meal did produce a $50 \%$ rise in the TRP:LNAA ratio but this was insufficient to change brain TRP, ${ }_{5} \mathrm{HT}$ or ${ }_{5} \mathrm{HIAA}$. A meal containing $200 \mathrm{~g}$ protein $/ \mathrm{kg}$ lowered brain ${ }_{5} \mathrm{HIAA}$ but had no effect at all on the 
ratio (Ashley et al. 1984; Ashley \& Leathwood, 1984). Carbohydrate or protein meals eaten by free-feeding rats had no effect on brain TRP or serotonin metabolism (P. D. Leathwood and L. Arimanana, unpublished results). In man, carbohydrate- or protein-containing evening meals have no effect at all on the TRP:LNAA ratio (Ashley et al. I982 and Fig. 4), although addition of $400 \mathrm{mg}$ TRP to the carbohydrate meal tripled the ratio. Calculated values for the ratio after combining TRP with the protein meal suggest that it would not even double (see Fig. 4).

\section{Effects on serotoninergic neurotransmission}

Having established the conditions under which diet-induced changes in plasma amino acids can influence brain serotonin, it is appropriate to ask if there is any evidence that this 'cascade' actually effects ${ }_{5} \mathrm{HT}$ release. One mechanism by which release might be maintained constant in the face of changing intraneuronal ${ }_{5} \mathrm{HT}$ is that firing rates might adapt. Moderate to large (i.e. $50 \mathrm{mg} / \mathrm{kg}$ or more) doses of

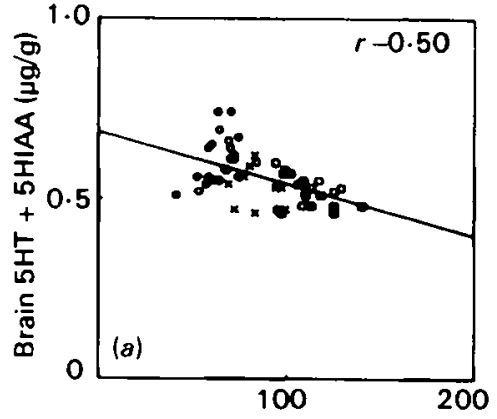

Plasma total TRP ( $\mu \mathrm{mol} / \mathrm{l})$

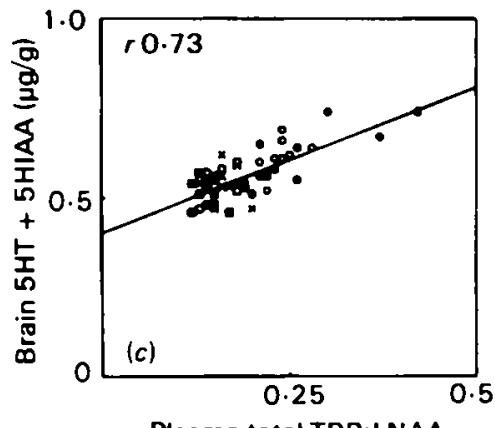

Plasma total TRP:LNAA
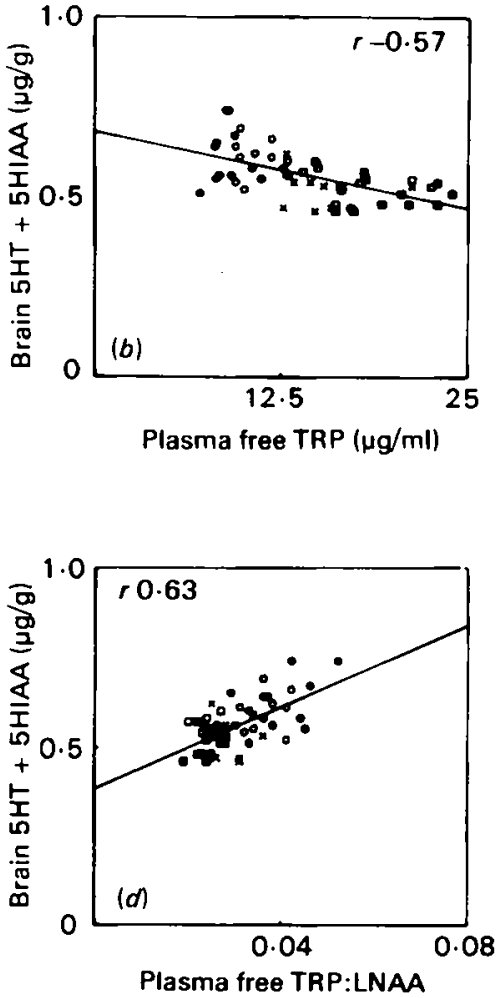

Fig. 3. Correlations between brain serotonin (5-hydroxytryptamine; $5 \mathrm{HT}$ ) plus 5 -hydroxyindoleacetic acid (5HIAA) and (a) plasma total tryptophan (TRP), (b) plasma free TRP, (c) plasma total TRP:large neutral amino acids (LNAA) ratio; $(d)$ plasma free TRP:LNAA ratio in rats fed on different meals following a 15 h overnight fast. Compositions of the meals were as follows: $2.5 \mathrm{~g}(O)$ or $5.0 \mathrm{~g}(\odot)$ of a high-carbohydrate, protein-free diet; $2.5 \mathrm{~g}(\square)$ or $5.0 \mathrm{~g}(\square)$ of a $200 \mathrm{~g}$ protein/kg diet; fasted control $(x)$. 

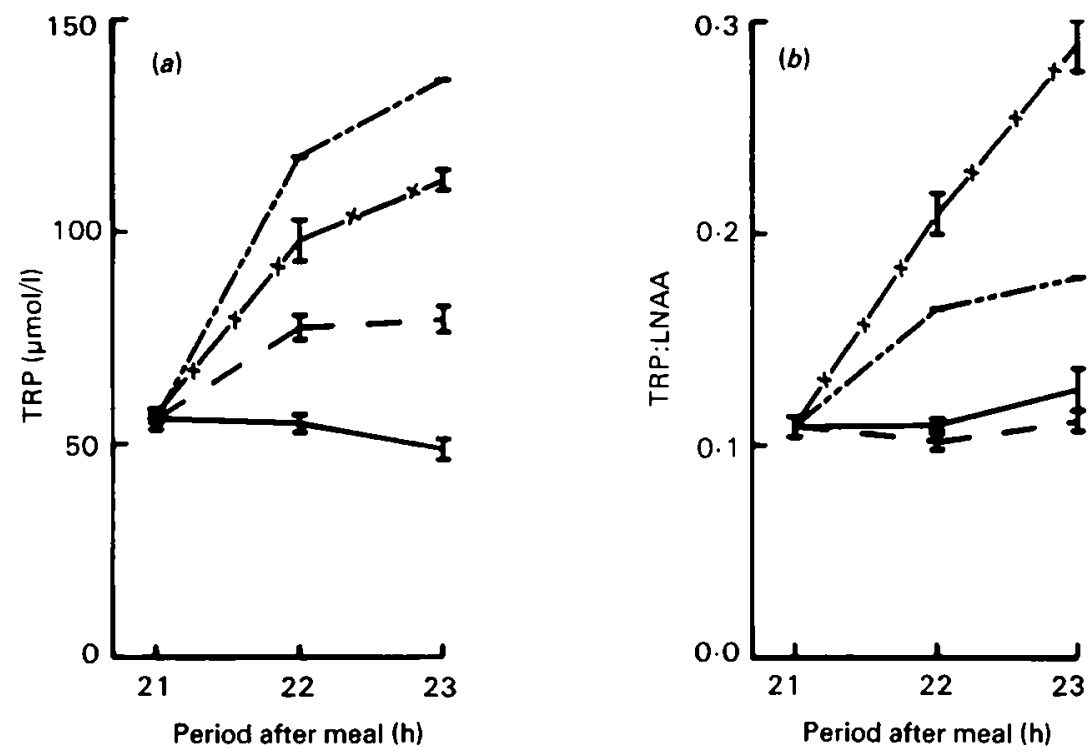

Fig. 4 (a) Plasma tryptophan (TRP) and (b) plasma TRP:large neutral amino acids (LNAA) ratio in healthy men given a carbohydrate-rich soup containing $70 \mathrm{~g}$ carbohydrate, $25 \mathrm{~g}$ fat and $\mathrm{I} .6 \mathrm{~g}$ protein (- $)$; a protein-rich soup containing $50 \mathrm{~g}$ carbohydrate, $25 \mathrm{~g}$ fat and $22 \mathrm{~g}$ protein ( - - - ) a carbohydrate-rich soup plus $400 \mathrm{mg}$ TRP $(-\mathbf{x}-\mathbf{x}-)$. Values for the protein-rich soup plus $400 \mathrm{mg}$ tryptophan $(-\cdots-$ ) were calculated. Values are means, with their standard errors represented by vertical bars. Adapted from Ashley et al. (1982).

TRP do slow the firing frequency of raphe neurons (Gallager \& Aghajanian, 1976). On the other hand, small, diet-induced changes in ${ }_{5} \mathrm{HT}(+\mathrm{I} 2$ to $-26 \%)$ did not change firing frequencies (Trulson, 1985) and so presumably did influence serotoninergic neurotransmission.

A second mechanism which might limit functional effects is that the 'extra' ${ }_{5} \mathrm{HT}$ synthesized might be metabolized intracellularly without entering the functional pool. Wolf \& Kuhn (1986) have recently shown in synaptosomes that raising TRP increases ${ }_{5} \mathrm{HT}$ synthesis but the ${ }_{5} \mathrm{HT}$ is immediately metabolized to ${ }_{5} \mathrm{HIAA}$ without being released. Extracellular ${ }_{5} \mathrm{HT}$ is also rapidly taken up and metabolized to ${ }_{5}$ HIAA. However, if the synaptosomes are depolarized, increasing TRP availability does increase $5 \mathrm{HT}$ release.

In summary, the evidence for or against TRP-induced increases in neurotransmission is inconclusive. Measurements of extracellular or CSF ${ }_{5}$ HIAA tell us little because it is impossible to know how much of the ${ }_{5} \mathrm{HIAA}$ comes from the 'functional' pool and how much comes directly from ${ }_{5} \mathrm{HT}$ that has not been released. An optimistic interpretation suggests that changes in intraneuronal ${ }_{5} \mathrm{HT}$ might influence release when firing rates are high. 
The role of serotonin in the brain

The majority of serotoninergic neurons in the mammalian central nervous system are located in the raphe nuclei of the brain stem. From these cell bodies, fine, slowly conducting fibres project throughout the brain (Moore, 1981). Most of the terminals seem to discharge into the extracellular fluid without making clear synaptic connections with other neurons. This anatomical lack of specificity has led to speculation that ${ }_{5} \mathrm{HT}$ acts as a 'modulator', having broad tonic effects rather than operating in a 'stimulus-response' mode (Bloom, 198r). This idea finds circumstantial support from analysis of the effects of ${ }_{5} \mathrm{HT}$ on the brain. The most consistent change following treatments which could be expected to produce a small increase in ${ }_{5} \mathrm{HT}$ availability is an increase in sleepiness or sedation (Garattini \& Valzelli, 1965; Wojcik et al. 1980; Young, 1985). Lowering $5 \mathrm{HT}$ produces insomnia or sustained arousal (Jouvet, 1973). In addition, ${ }_{5} \mathrm{HT}$ has been reported to influence arousal, temperature regulation, pain sensitivity, sexual behaviour and aggression (Garattini \& Valzelli, 1965; Hoebel, 1977; Fernstrom, 1983; Jouvet, 1983; Young, 1985), with a general tendency to be associated with a tonic suppression of these functions (for review, see Stein \& Wise, 1974).

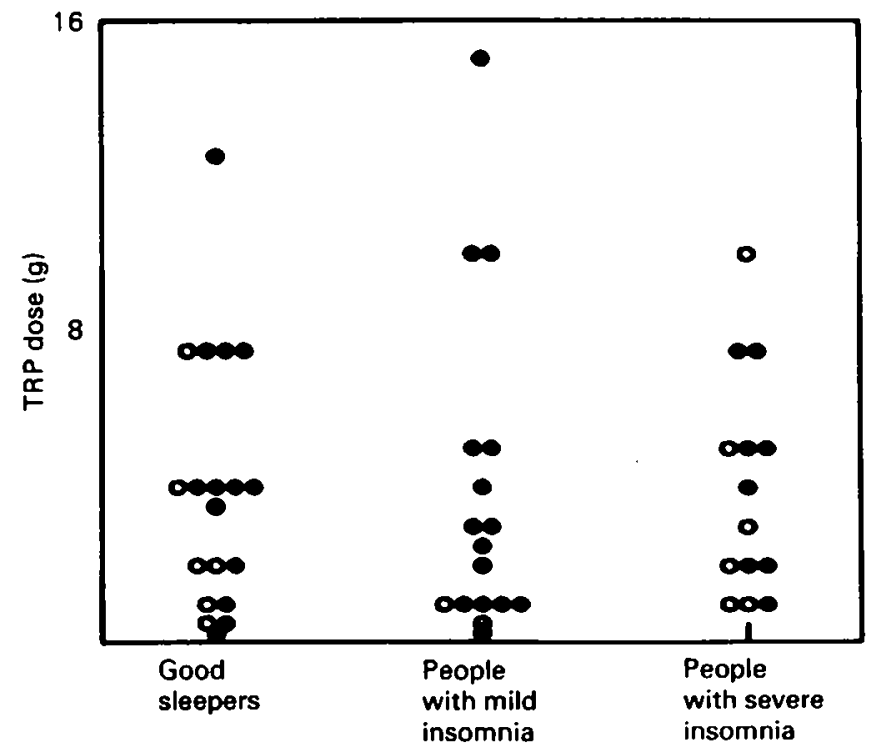

Fig. 5. A summary of the results of nearly forty different studies on the effect of tryptophan (TRP) on sleep in man comparing the effects of different doses of TRP on three types of subjects: (I) good sleepers, (2) people with mild insomnia or long sleep latency, (3) people suffering from chronic or severe insomnia. Points represent individual studies in which the indicated dose of TRP was with $(O)$ or without $(O)$ a sedative effect. From Hartman \& Greenwald (1984). 


\section{TRP and sleep}

Serotonin seems to play a role in the triggering of the onset of sleep but the mechanism involved is still not clearly understood (Jouvet, I 983 ; Koella, I 984). On the one hand, lowering brain ${ }_{5} \mathrm{HT}$ by pharmacological or surgical means produces insomnia. Re-establishing ${ }_{5} \mathrm{HT}$ levels leads, after a fixed delay of about $45 \mathrm{~min}$, to sleep onset. On the other hand, $5 \mathrm{HT}$ release and neuronal activity are maximal during arousal. A plausible explanation for this apparent contradiction is that ${ }_{5} \mathrm{HT}$ release during arousal has a cumulative effect, gradually increasing the propensity to fall asleep (see Jouvet, 1983 ).

As TRP can increase brain ${ }_{5} \mathrm{HT}$ levels, there have been many clinical studies on its effectiveness as a sedative. Fig. 5 (adapted from Hartman \& Greenwald, 1984) summarizes the results of nearly forty different experiments. It shows that TRP is relatively ineffective in normal 'good sleepers' and in patients with severe insomnia. However, in doses of $\mathrm{I} g$ or more it consistently reduces sleep latency in people with mild insomnia or long sleep latencies. In two recent studies (Leathwood \& Pollet, 1983, 1984) on over 100 volunteers, we have shown that 500 mg TRP combined with a carbohydrate load is also an effective sedative. This dose should be enough to produce a $10-20 \%$ rise in brain ${ }_{5} \mathrm{HT}$.

\section{TRP and mood}

The observations that ${ }_{5} \mathrm{HT}$ tends to produce tonic suppression in a variety of brain functions and behaviours provides the theoretical framework for the use of TRP in treating mania, chronic pain, pathological aggression and hypersexuality. For some of these problems, large doses of TRP have been used with success (for review, see Young, 1985) but results have been inconsistent. Although much of this variability is probably linked to the biochemical heterogeneity of the syndromes being treated, it is appropriate to look at the studies from a nutritional viewpoint to see if the composition of meals eaten with the TRP load might influence its availability to the brain. This is important because the validating studies demonstrating, in man, that TRP increases CSF and brain ${ }_{5} \mathrm{HT}$ metabolites (Eccleston et al. 1970; Gillman et al. 1981; Young \& Gauthier, 1981) have used patients fasted overnight and given TRP alone. In clinical practice, TRP is usually given in doses of about $2 \mathrm{~g}$, in combination with a meal (Young, 1985). Table I shows how the composition of meals eaten concommitantly with the TRP load would be expected to influence brain ${ }_{5} \mathrm{HT}$ if all the assumptions in the hypothesis outlined above are correct. The changes in plasma TRP after the TRP load have been calculated from the values of Eccleston et al. (1970); the effects of different meals on plasma amino acids from Fernstrom et al. (1979), and the extrapolation to changes in brain ${ }_{5} \mathrm{HT}$ and ${ }_{5} \mathrm{HIAA}$ from the correlation in Fernstrom \& Wurtman (1972). It can be seen that, according to the composition of the meal, the same $2 \mathrm{~g}$ load of TRP may produce anything from a $7 \%$ to a $50 \%$ rise in brain ${ }_{5} \mathrm{HT}$ and ${ }_{5} \mathrm{HIAA}$. Thus it should hardly be surprising that clinical studies have, so far, produced inconsistent results. 
Table I. Estimated changes in plasma tryptophan (TRP) and large neutral amino acids (LNAA) after consuming $2 \mathrm{~g} T R P$ with different midday meals in man

\begin{tabular}{|c|c|c|c|c|}
\hline \multirow[b]{2}{*}{ Measurements } & \multicolumn{3}{|c|}{ Protein content of meal $(\mathrm{g})$} & \multirow[b]{2}{*}{ References } \\
\hline & 50 & 25 & $\circ$ & \\
\hline $\begin{array}{l}\text { Increase in plasma TRP } \\
2 \mathrm{~h} \text { after a } 2 \mathrm{~g} \text { TRP } \\
\text { load (mM) }\end{array}$ & I 50 & $15^{\circ}$ & I 50 & $\begin{array}{l}\text { Values extrapolated from } \\
\text { Eccleston et al. ( } 1970)\end{array}$ \\
\hline $\begin{array}{l}\text { Plasma TRP } 2 \mathrm{~h} \\
\text { after meal (mM) }\end{array}$ & 80 & 60 & 40 & $\begin{array}{l}\text { Values from Fernstrom } e t \text { al. } \\
\text { (1979) }\end{array}$ \\
\hline $\begin{array}{l}\text { Total LNAA } 2 \mathrm{~h} \\
\text { after meal (mM) }\end{array}$ & II 40 & 630 & 270 & $\begin{array}{l}\text { Values from Fernstrom et al. } \\
\text { (I } 979 \text { ) }\end{array}$ \\
\hline TRP:LNAA ratio & 0.20 & 0.33 & 0.77 & \\
\hline $\begin{array}{c}\text { Expected change in } \\
\text { brain }{ }_{5} \mathrm{HT}(\%)\end{array}$ & +7 & +14 & +50 & $\begin{array}{l}\text { Values extrapolated from } \\
\text { Fernstrom \& Wurtman (1972) }\end{array}$ \\
\hline
\end{tabular}

Several studies have set out to examine the effects of manipulating precursor availability in normal subjects. With large doses of TRP the most commonly reported effect is a mixture of drowsiness and euphoria, but with dizziness, headache and nausea as side effects (Smith \& Prockop, 1962; Greenwood et al. 1975). Lowering the plasma TRP:LNAA value by giving large ( $100 \mathrm{~g})$ doses of a mixture of LNAA produces a lowering of mood (Young, 1985 ).

In a double-blind, placebo controlled trial, Leathwood \& Pollet (1983) examined the effects of $500 \mathrm{mg}$ TRP combined with a $50 \mathrm{~g}$ carbohydrate load on mood, sleepiness and appetite in sixty volunteers. The TRP-carbohydrate mixture led to feelings of lethargy and sleepiness, and was perceived as sedating. Hunger and protein-carbohydrate preferences were unaffected and there were no untoward side effects. The results also suggested that there was a subgroup of 'responders', i.e. people who consistently felt sedated after TRP-carbohydrate.

There have also been reports that fasted volunteers feel more sleepy after a carbohydrate meal compared with a protein meal and that, in children, a carbohydrate-rich drink lowers spontaneous activity relative to an artificially sweetened drink (Spring et al. 1983; Lieberman, 1986). These changes are in the direction predicted by the expected effects of protein and carbohydrate (consumed after a fast) on brain ${ }_{5} \mathrm{HT}$, but we are still a long way from demonstrating that this really is the mechanism involved.

\section{${ }_{5} H T$ and protein-carbohydrate selection}

If rats are starved overnight and then fed on a carbohydrate meal, the plasma TRP:LNAA ratio and brain TRP and ${ }_{5} \mathrm{HT}$ concentrations increase. A protein meal can have the opposite effect (Fernstrom \& Wurtman, 1974; Figs. 2 and 3). Curiously, these observations have been extrapolated to the generalization that any carbohydrate meal will, by the same mechanism, increase brain ${ }_{5} \mathrm{HT}$ and any 

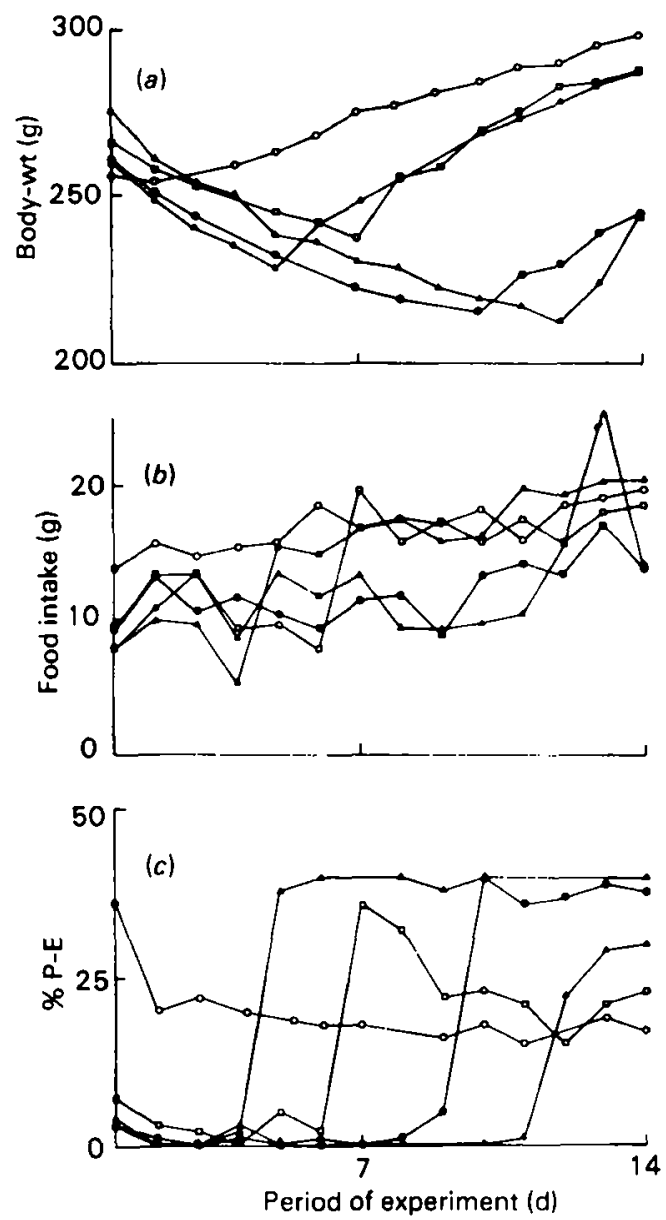

Fig. 6. (a) Body-weights, $(b)$ food intake and (c) percentage of energy as protein (\% P-E) selected by five adult male rats offered a choice of $o$ and $400 \mathrm{~g}$ casein $/ \mathrm{kg}$ diets during 2 weeks. Most animals initially selected inadequate amounts of protein. They lost weight and ate less food. After anything from 4 to II $\mathrm{d}$ they abruptly began to eat the $400 \mathrm{~g}$ casein $/ \mathrm{kg}$ diet. Food intake immediately increased and body-weight began to rise.

protein meal will lower it (for example, see Wurtman, 1973; Fernstrom \& Wurtman, 1974; Fernstrom, 1983; Harper \& Peters, 1983; Spring et al. 1983; Blundell, 1984; Lieberman, I986). In turn, this has led to the hypothesis that ${ }_{5} \mathrm{HT}$ might operate as a 'variable ratio sensor' detecting and determining the proportions of energy selected as protein and carbohydrate in the diet.

First, is protein-carbohydrate selection regulated? In the paradigm most often used to examine this question, animals are allowed to select from two diets, one low in protein and high in carbohydrate, the other high in protein and with little carbohydrate. For convenience, the selection pattern is usually expressed in 
percentage of energy selected in the form of protein (\% P-E). Although this technique appears simple and straightforward, it is beset with methodological difficulties (Blundell, r983) and results have been contradictory. Musten et al. (1974) reported that, over a range of diet pairs, rats appeared to select about $30 \%$ P-E. (This is about double the requirement for adequate growth.) Unfortunately, others have not been able to confirm this tight pattern of selection. Leathwood \& Ashley $(1983 a)$ noted that rats offered a choice of low- and high-protein diets may take up to $10 \mathrm{~d}$ to select adequate and stable levels of protein intake (Fig. 6). Even then, the range is extremely wide (e.g. $15-62 \%$ P-E) and selection can be influenced by the composition, taste and texture of the diets as well as by the age of the animals (Bise et al. 1973; Leathwood \& Ashley, 1983a,b; Leathwood \& Arimanana, 1984). Furthermore, if the diet pairs are changed, \% P-E selected also changes (Fig. 7). This suggests that, while stable selection patterns can occur and animals tend to avoid extremely high- or low-protein intakes, there is not much evidence for a mechanism tightly regulating protein-carbohydrate selection.

Second, if ${ }_{5} \mathrm{HT}$ is part of a feedback link detecting and then influencing choice of protein and carbohydrate, the proportions of protein and carbohydrate eaten should influence brain ${ }_{5} \mathrm{HT}$. As pointed out earlier, this mechanism does seem to function after a period of starvation, but after short fasts or during free-feeding the

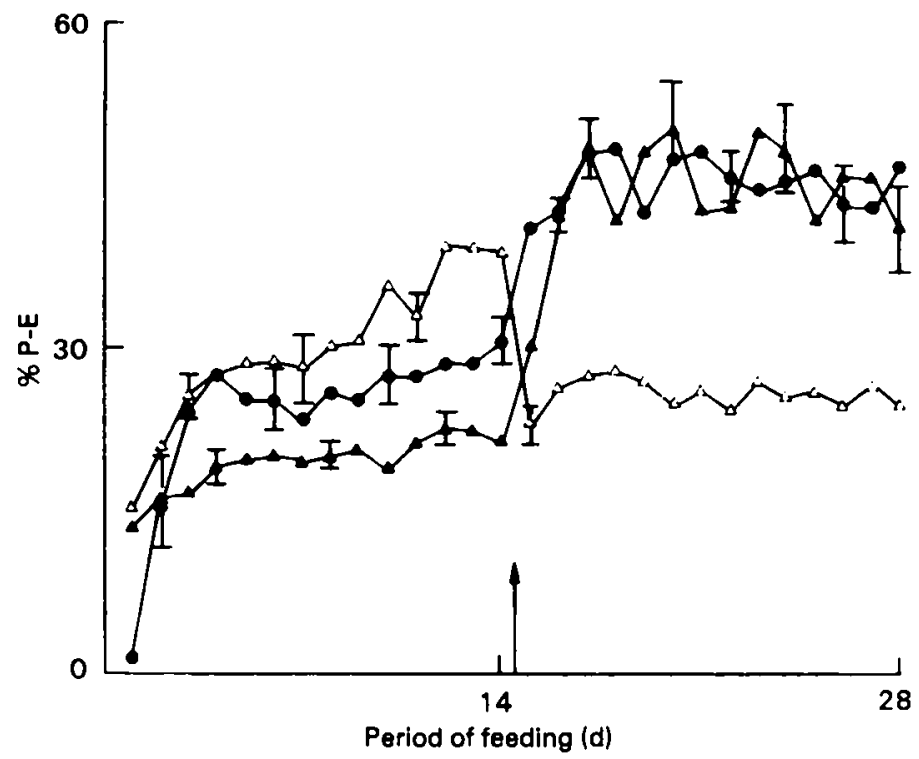

Fig. 7. Mean percentage energy as protein (\% P-E) selection by three groups of weanling rats offered the following amounts of casein. Group I (- - ) period I (days I-14) 0 and $400 \mathrm{~g}$ casein/kg diets; period 2 (days $15-28$ ), 200 and $600 \mathrm{~g} / \mathrm{kg}$. Group 2 (- - -): period 1,0 and 600 $\mathrm{g} / \mathrm{kg}$; period 2, 100 and $400 \mathrm{~g} / \mathrm{kg}$. Group $3(-\Delta-)$ : period $\mathrm{I}, 100$ and $400 \mathrm{~g} / \mathrm{kg}$; period 2,0 and $600 \mathrm{~g}$ casein $/ \mathrm{kg}$ diets. $\uparrow$, Change in diets offered. Points are means with their standard errors represented by vertical bars. 
composition of the last meal either does not affect the plasma TRP:LNAA ratio or the change is so small that brain TRP and ${ }_{5} \mathrm{HT}$ concentrations do not change (Ashley et al. I982, I984). If the composition of individual meals is unlikely to influence brain ${ }_{5} \mathrm{HT}$, perhaps long-term eating patterns will. Several groups have reported weak correlations in the expected direction between \% P-E (selected or imposed) and plasma TRP:LNAA, but no detectable changes in brain ${ }_{5} \mathrm{HT}$ or 5HIAA (Harper \& Peters, 1983; Leathwood \& Ashley, 1983a,b; Fernstrom et al. 1985; Peters \& Harper, 1985 ).

Third, if the hypothesis is to have any value, changes in brain ${ }_{5} \mathrm{HT}$ availability should have predictable effects on consumption of carbohydrate and protein. If rats are fasted, given an oral dose of TRP and then offered a choice of high- and low-protein diets, they do select a significantly higher \% P-E than expected (Li \& Anderson, 1982; Arimanana et al. 1984). Similarly, if rats are fasted for $16 \mathrm{~h}$ and then given a small dose of fenfluramine (a $5 \mathrm{HT}$ re-uptake blocker), they select proportionately more protein. In free-feeding rats, however, neither fenfluramine nor TRP has any effect on selection (Harper \& Peters, I983; Blundell, 1984). In man, amounts of TRP which might be expected to influence ${ }_{5} \mathrm{HT}$ synthesis do not seem to change protein-carbohydrate preference or \% P-E selected, nor do they influence food intake in people who are 'carbohydrate cravers' (Leathwood \& Pollet, 1983; Hrboticky et al. 1985; Strain et al. 1985).

In summary, the current evidence for a feed-back control of protein-carbohydrate selection via plasma TRP:LNAA-induced changes in brain ${ }_{5} \mathrm{HT}$ synthesis is very weak. In the special case of eating after a fast, brain ${ }_{5} \mathrm{HT}$ availability may induce small changes in selection, but the ecological significance of such an effect is obscure.

\section{Conclusions}

Consumption of TRP can increase the rate of ${ }_{5} \mathrm{HT}$ synthesis in the brain. A similar effect can be seen when a carbohydrate meal is eaten following a prolonged fast, and carbohydrate can potentiate the effect of a TRP load. Direct evidence for a change in serotoninergic neurotransmission is still inconclusive, but indirect clinical and pharmacological observations suggest that serotoninergic function can be changed. TRP combined with carbohydrate does seem to have useful sedative properties, and may also find applications in the treatment of mania and aggression once an effective method of administration is achieved. On the other hand, the evidence for a feed-back mechanism influencing selection of protein and carbohydrate is still far from convincing.

\section{REFERENCES}

Arimanana, L., Ashley, D. V., Furniss, D. \& Leathwood, P. D. (1984). In Progress in Tryptophan and Serotonin Research, pp. 549-552 [H. Schlossberger, W. Kochen, B. Linzen and H. Steinhart, editors]. Berlin: De Gruyter.

Ashley, D. V., Barclay, D. V., Chauffard, F. A., Moennoz, D. \& Leathwood, P. D. (1982). American fournal of Clinical Nutrition 36, $143^{-1} 53$. 
Ashley, D. V. \& Leathwood, P. D. (1984). In Progress in Tryptophan and Serotonin Research. pp. 579-582 [H. Schlossberger, W. Kochen, B. Linzen and H. Steinhart, editors]. Berlin: De Gruyter.

Ashley, D. V., Leathwood, P. D. \& Moennoz, D. (1984). In Progress in Tryptophan and Serotonin Research, pp. 591-594 [H. Schlossberger, W. Kochen, B. Linzen and H. Steinhart, editors]. Berlin: De Gruyter.

Biggio, G., Fadda, F., Fanni, P., Tagliamonte, A. \& Gessa, G. L. (1974). Life Sciences 14, I321-1329.

Bise, A., Leathwood, P. D. \& Ashley, D. V. (1973). International fournal of Vitamin and Nutrition Research 53, 232.

Bloom, F. E. (1981). In Serotonin Neurotransmission and Behavior, pp. 403-424 [B. Jacobs and A. Gelperin, editors]. Cambridge, Mass: MIT Press.

Blundell, J. E. (1983). In Nutrition and the Brain, vol. 6, pp. I63-22 I [R. J. Wurtman and J. J. Wurtman, editors]. New York: Raven Press.

Blundell, J. E. (1984). Neuropharmacology 23, $1537-155$ I.

Carlsson, A. \& Lindqvist, M. (1972). Journal of Neural Transmission 33, 23-43.

Eccleston, D., Ashcroft, G. W., Crawford, T. B., Stanton, J. B., Wood, D. \& McTurk, P. H. (r970). Journal of Neurology, Neurosurgery and Psychiatry 33, 269-272.

Fernstrom, J. D. (1983). Physiological Reviews 63, 484-546.

Fernstrom, J. D., Fernstrom, M. H., Grubb, P. E. \& Volk, E. A. (1985). Fournal of Nutrition I I5, 1337-1344.

Fernstrom, J. D., Madras, B. K., Munro, H. N. \& Wurtman, R. J. (1974). In Aromatic Amino Acids in the Brain, Ciba Foundation Symposium no. 22, pp. 153-165. Amsterdam: Elsevier.

Fernstrom, J. D. \& Wurtman, R. J. (1971). Science 174, $1023-1025$.

Fernstrom, J. D. \& Wurtman, R. J. (1972). Science 178, 414-416.

Fernstrom, J. D. \& Wurtman, R. J. (1974). Scientific American 230, 84-91.

Fernstrom, J. D., Wurtman, R. J., Hammarstrom-Wiklund, B., Rand, W. M., Munro, H. N. \& Davidson, C. S. (1979). American Fournal of Clinical Nutrition 32, $1912-1922$.

Gallager, D. W. \& Aghajanian, G. K. (1976). Neuropharmacology 15, 149-1 56.

Garattini, S. \& Valzelli, L. (1965). Serotonin. Amsterdam: Elsevier.

Gillman, P. K., Bartlett, J. R., Bridges, P. K., Hunt, A., Patel, A. J., Kantamaneni, B. D. \& Curzon, G. (1981). Journal of Neurochemistry 37, 410-417.

Greenwood, M., Lader, M. H., Kantamaneni, B. D. \& Curzon, G. (1975). British Journal of Clinical Pharmacology 2, 165-1 72.

Harper, A. E. \& Peters, J. C. (1983). Experientia 44, Suppl., 107-134.

Hartman, E. \& Greenwald, D. (1984). In Progress in Tryptophan and Serotonin Research, pp. 291-296 [H. Schlossberger, W. Kochen, B. Linzen and H. Steinhart, editors]. Berlin: De Gruyter.

Hess, S. M. \& Doepfer, W. (1961). Archives Internationales de Pharmacodynamie et de Thérapie I34, 89-99.

Hoebel, B. G. (1977). In Handbook of Psychopharmacology, vol. 8, pp. 55-129 [L. Iverson, S. Iverson and S. Snyder, editors]. New York: Plenum Press.

Hrboticky, N., Leiter, L. A. \& Anderson, G. H. (1985). Nutrition Research 5, 595-607.

Jouvet, M. (1973). In Serotonin and Behavior, pp. 385-400 [J. Barchas and E. Usdin, editors]. New York: Academic Press.

Jouvet, M. (1983). In Sleep 1982, pp. 2-18 [W. Koella, editor]. Basel: Karger.

Kaufman, S. (1 974). In Aromatic Amino Acids in the Brain, Ciba Foundation Symposium no. 22, pp. 85-107. Amsterdam: Elsevier.

Koella, W. P. (1984). Experientia 40, 309-337.

Leathwood, P. D. (1986). In Nutrition and Neurobiology, pp. 54-7I [J. Somogyi and D. Hötzel, editors]. Basel : Karger.

Leathwood, P. D. \& Arimanana, L. (1984). Annual Review of Chronopharmacology I, 255-262.

Leathwood, P. D. \& Ashley, D. V. (1983a) Appetite 4, 97-1 12.

Leathwood, P. D. \& Ashley, D. V. (1983b) Experientia 44, Supp., 171-196.

Leathwood, P. D. \& Pollet, P. (1983). Fournal of Psychiatric Research 17, 147-1 54.

Leathwood, P. D. \& Pollet, P. (1984). In Progress in Tryptophan and Serotonin Research. pp. $3 I_{1}-3 I_{4}$ [H. Schlossberger, W. Kochen, B. Linzen and H. Steinhart, editors]. Berlin: De Gruyter. 
Li, E. T. \& Anderson, G. H. (1982). Physiology and Behavior 29, 779-783.

Lieberman, H. J. (1986). In Nutrition and Neurobiology, pp. $219-224$ [J. Somogyi and D. Hötzel, editors]. Basel: Karger.

Macon, J. B., Sokoloff, L. \& Glowinski, J. (I971). Fournal of Neurochemistry 18, 323-331.

Moore, R. Y. ( $198 \mathrm{~s}$ ). In Serotonin Neurotransmission and Behavior, pp. 35-7I [B. Jacobs and A. Gelperin, editors]. Cambridge, Mass: MIT Press.

Musten, B., Peace, D. \& Anderson, G. H. (1974). Fournal of Nutrition r04, 563-572.

Pardridge, W. M. (1983). Physiological Reviews 63, 1481-1 535.

Pérez-Cruet, J., Chase, T. N. \& Murphy, D. L. (1974). Nature 248, 693-695.

Peters, J. C. \& Harper, A. E. (1985). Fournal of Nutrition 115, 382-389.

Smith, B. \& Prockop, D. J. ( I962). New England fournal of Medicine 267, I338-1 341 I.

Spring, B., Maller, O., Wurtman, J. J., Digman, L. \& Cozolino, L. (1983). Fournal of Psychiatric Research $17,155^{-167 .}$

Stein, L. \& Wise, C. D. (1974). Advances in Biochemical Psychopharmacology 112, 281-291.

Strain, G. W., Strain, J. J. \& Zumoff, B. (1985). International Yournal of Obesity 9, 375-380.

Sved, A. F. (1983). In Nutrition and the Brain, vol. 6, pp. 223-276 [R. J. Wurtman and J. J. Wurtman, editors]. New York: Raven Press.

Trulson, M. E. (1985). Life Sciences 37, 1067-1072.

Wojcik, W. J., Fornal, C. \& Radulovacki, M. (1980). Neuropharmacology 19, I63-167.

Wolf, W. A. \& Kuhn, D. M. (1986). Fournal of Neurochemistry 46, $61-67$.

Wurtman, R. J. (1973). In Serotonin and Behavior, p. 446 [J. Barchas and E. Usdin, editors]. New York: Academic Press.

Wurtman, R. J., Hefti, F. \& Melamed, E. (1981). Pharmacological Reviezos 32, 315-335.

Young, S. N. (1985). In Nutrition and the Brain, vol. 7, pp. 49-88 [R. J. Wurtman and J. J. Wurtman, editors]. New York: Raven Press.

Young, S. N. \& Gauthier, S. (1981). Fournal of Neurology, Neurosurgery and Psychiatry 44, $323-327$. 